\title{
Genetic polymorphism of candidate genes in pig meat production
}

\author{
Zuzana Lieskovská ${ }^{1}$ - Anton Kováčik ${ }^{2}$ - Anna Trakovická ${ }^{1}$ \\ ${ }^{1}$ Slovak University of Agriculture in Nitra, Department of Animal Genetics and Breeding Biology, \\ Tr. A. Hlinku 2, 94976 Nitra, The Slovak Republic \\ ${ }^{2}$ Slovak University of Agriculture in Nitra, Department of Animal Physiology, \\ Tr. A. Hlinku 2, 94976 Nitra, The Slovak Republic \\ z.lieskovska@gmail.com
}

Keywords: H-FABP, LEPR, MC5R, PCR-RFLP, polymorphism

\section{SUMMARY}

$H-F A B P, L E P R$ and MC5R genes were suggested as candidate genes for fat content in pig meat. The aim of this study was to detect genetic variation in the porcine H-FABP, LEPR and MC5R genes by PCR-RFLP method in a group of pigs. Genotyping of pigs was done by PCRRFLP methods. We identified three genotypes in the set of pigs, HH (0.504), Hh (0.412) and hh (0.084) for H-FABP (HinfI). Allele H showed higher frequency than allele $h(0.710$ vs. 0.290). Three genotypes were identified for the H-FABP (HaeIII) gene (DD - 0.194, Dd - 0.494, dd - 0.312). The allele D (0.441) showed slightly lower frequency than allele d (0.559). All three genotypes were identified for LEPR (HpaII) in the group of pigs $(A A-0.137, A B-0.314, B B-0.549)$. Higher frequency of LEPR gene was confirmed for allele $B(0.706)$, as compared with allele A (0.294). We identified two genotypes for MC5R (BsaHI) in the group of pigs (AA - 0.348 and AG - 0.652), genotype GG was not found. As conforms with genotype structure, we recognize a higher frequency of allele $A(0.674)$ as compared with allele $G(0.326)$.

\section{INTRODUCTION}

In the process of pig interbreeding, as well as that of other farming animals, the aim of breeders is to achieve the best possible productive results and traits derived from several molecular-genetic methods. Demand for lean pork meat results in breeding programs aimed at fat reduction. Therefore, we have decided to focus on the polymorphism candidate genes which have an effect on pork production, among which we include: $H-F A B P$, LEPR and MC5R.

The $H-F A B P$ gene codes for a protein are related to the intracellular transport of fatty acid and play an important role in the regulation of lipid metabolism. Given this physiological role, $H$ - $F A B P$ has been considered an interesting candidate gene for intramuscular fat and backfat thickness in pigs. Gerbens et al. (1997). The HFABP is a protein present in several tissues with a high damage for fatty acids, such as cardiac and skeletal muscle and lactating mammary glands.

The porcine $H$-FABP gene was localized on chromosome 6 by porcine sequence-specific PCR on DNA from a pig/rodent cell hybrid panel (Gerbens et al., 1997). PCR-RFLP analysis detected three polymorphic sites in the porcine H-FABP gene (HaeIII, HinfI, MspI) (Gerbens et al., 1997).

Leptin, a product of the LEP gene, is secreted in adipose tissue and signals to the hypothalamus that the body has been saturated. Expression and secretion of leptin is obviously related to food intake regulation, energy metabolism and body weight (Campfield et al., 1995, Remesar et al., 1997). Its receptor (leptin receptor, LEPR) has been localized to several hypothalamic nuclei, including the ventromedial hypothalamus, the medial preoptic area, the paraventricular nucleus, and the arcuate nucleus (Keen-Rhinehart et al. 2004). Vincent (1997) identified a HinfI polymorphism in LEPR gene and mapped its location to pig chromosome 6. Stratil (1998) identified two other types of polymorphism with the restriction enzymes HpaII and RsaI. Emnett et al. (2001) confirmed the $L E P R(M b o \mathrm{I})$ genetic effect on average daily gain.

Among candidate genes with an effect on the content of fat in pork belongs gene of melanocortic receptor MC5R. Gene MC5R belongs to the family of melanocorticotrophic genes and coding the systems of receptor for adenocorticotrophic hormone. Kim et al. 2000 localized $M C 5 R$ gene to pigs 6 chromosome. Kim et al., 2000 detected two types of $M C 5 R$ gene polymorphism by using restriction enzyme $B s a H I$ with splitting polymorphic fragments A (238 bp) and G (179 bp and $59 \mathrm{bp})$. Second type of polymorphism detected by specific PCR shows alleles C (128 bp) and T (118 bp). Protein MC5R is a mediator for thermoregulation, secretion of glands and sexual behavior (Kim et al., 2000). The analysis of a whole population shows the significant influence of the $M C 5 R$ (BsaHI) gene on backfat thickness where the allele A was in association with higher backfat thickness (Emnett et al., 2001).

Application of these candidate genes direct in selection programs give possible way to obtain decrease backfat thickness, without reduction of intramuscular fat. 


\section{MATHERIAL and METHODS}

In our experiment were used 105 pigs (Large white). Genomic DNA from the blood of pigs was isolated by proteolytic hydrolysis using proteinase $\mathrm{K}$, phenol-chloroform deprotenization and ethanol precipitation according Sambook et al. (1989). Genotyping of pigs was done by PCR-RFLP methods.

Primer pairs for PCR amplification

Table 1

\begin{tabular}{|c|c|}
\hline Gene & Primer sequence \\
\hline $\begin{array}{l}\text { H-FABP } \\
\text { (HaeIII) }\end{array}$ & $\begin{array}{l}\text { FOR } \\
5^{\prime} \text { ATTGCTTCGGTGTGTTTGAG - } 3 \\
\text { REV } \\
5^{\prime}-\text { TCAGGAATGGGAGTTATTGG - } 3\end{array}$ \\
\hline $\begin{array}{l}\text { H-FABP }^{2} \\
(\text { HinfI })\end{array}$ & $\begin{array}{l}\text { FOR } \\
5^{\prime} \text { - GGACCCAAGATGCCTACGCCG - } 3 \\
\text { REV } \\
5^{\prime} \text { CTGCATCTTTGACCAAGAGG - 3' }\end{array}$ \\
\hline $\begin{array}{l}\text { LEPR }^{3} \\
(\text { HpaII) }\end{array}$ & $\begin{array}{l}\text { FOR } \\
5 \text { - GGAAGGCATTTGTTTCAGCAGTAA - } 3 \\
\text { REV } \\
5 \text { - CAAGTCCTCTTTCATCCAGCACTG - } 3\end{array}$ \\
\hline $\begin{array}{l}\mathrm{MC5R}^{4} \\
(\mathrm{BsaHI})\end{array}$ & $\begin{array}{l}\text { FOR } \\
\text { 5' - TGAGCCTCTTGGAGAACATC-3' } \\
\text { REV } \\
5^{\prime} \text { - GCCACCAAGGAGATGCAG - 3' }\end{array}$ \\
\hline
\end{tabular}

Time and temperature profile PCR reaction

\begin{tabular}{|c|c|c|c|c|c|c|c|c|}
\hline & \multicolumn{2}{|c|}{$\begin{array}{l}\text { H-FABP } \\
\text { (HaeIII) }\end{array}$} & \multicolumn{2}{|c|}{$\begin{array}{l}\text { H-FABP } \\
\text { (HinfI) }\end{array}$} & \multicolumn{2}{|c|}{$\begin{array}{l}\text { LEPR } \\
\text { (HpaII) }\end{array}$} & \multicolumn{2}{|c|}{$\begin{array}{l}\text { MC5R } \\
(B s a H I)\end{array}$} \\
\hline Start & $95^{\circ} \mathrm{C}$ & 2 min. & $94^{\circ} \mathrm{C}$ & $3 \mathrm{~min}$. & $95^{\circ} \mathrm{C}$ & $2 \mathrm{~min}$. & $94^{\circ} \mathrm{C}$ & $3 \mathrm{~min}$. \\
\hline Denaturation & $95^{\circ} \mathrm{C}$ & $30 \mathrm{sec}$. & $94^{\circ} \mathrm{C}$ & $1 \mathrm{~min}$. & $94^{\circ} \mathrm{C}$ & $1 \mathrm{~min}$. & $94^{\circ} \mathrm{C}$ & $30 \mathrm{sec}$. \\
\hline Annealing & $57^{\circ} \mathrm{C}$ & $30 \mathrm{sec}$. & $57^{\circ} \mathrm{C}$ & $1 \mathrm{~min}$. & $55^{\circ} \mathrm{C}$ & $1 \mathrm{~min}$. & $56^{\circ} \mathrm{C}$ & $1 \mathrm{~min}$. \\
\hline Polymerization & $72^{\circ} \mathrm{C}$ & $90 \mathrm{sec}$. & $72^{\circ} \mathrm{C}$ & $1 \mathrm{~min}$. & $72^{\circ} \mathrm{C}$ & 2 min. & $72^{\circ} \mathrm{C}$ & $30 \mathrm{sec}$. \\
\hline Elongation & $72^{\circ} \mathrm{C}$ & $10 \mathrm{~min}$. & $72{ }^{\circ} \mathrm{C}$ & $10 \mathrm{~min}$. & $72{ }^{\circ} \mathrm{C}$ & $10 \mathrm{~min}$. & $72{ }^{\circ} \mathrm{C}$ & $10 \mathrm{~min}$. \\
\hline Cooling & $15^{\circ} \mathrm{C}$ & forever & $15^{\circ} \mathrm{C}$ & forever & $15^{\circ} \mathrm{C}$ & forever & $15^{\circ} \mathrm{C}$ & forever \\
\hline Cycles & \multicolumn{2}{|c|}{30} & \multicolumn{2}{|c|}{33} & \multicolumn{2}{|c|}{30} & \multicolumn{2}{|c|}{30} \\
\hline
\end{tabular}

H-FABP (HaeIII): The 850 bp product was digested by HaeIII restriction enzyme (Fermentas). PCR restriction fragments (allele D 850 bp and allele d $450+400 \mathrm{bp}$ ) were separated on $2 \%$ agarose gel.

H-FABP (HinfI) : The PCR products of $700 \mathrm{bp}$ were digested by HinfI restriction enzyme (Promega). Restriction digestion fragments were separated on $3 \%$ agarose gel (SIGMA).

LEPR (HpaII): The PCR products of 2000 bp were digested by HpaII restriction enzyme and fragments (allele A $2000 \mathrm{bp}$ and B $1450+550 \mathrm{bp}$ ) were separated on $1.5 \%$ agarose gel.

MC5R (BsaHI): Amplified PCR products were splitted by restriction enzyme BsaHI. Obtained fragments A (238 bp) and $\mathrm{G}(179 \mathrm{bp})$ were visualized in $3.0 \%$ agarose gel (Table 1-2).

\section{RESULTS and DISCUSION}

Out of the PCR-RFLP analysis results were calculated frequencies of genotypes and alleles. Genetic structure of observed genes is presented in Table 3. Effectiveness of the alleles was evaluated and presented in Table 4.

\section{H-FABP (HinfI)}

We identified three genotypes in the set of pigs, $\mathrm{HH}(0.504)$, Hh (0.412) and hh (0.084). Allele $\mathrm{H}$ showed higher frequency than allele h (0.710 vs. 0.290). Nechtelberger (2001) confirmed high occurrence of $\mathrm{H}$ allele in Large White and Landrace breeds. Mindeková etal. (2006) and Kováčik et al. (2010) found a similar frequency of allele $\mathrm{H}$ (0.678 or 0.686) in crossbred pigs (Large White x Landrace). Lee et al. 2010 also found high frequency of $\mathrm{H}$ allele (0.64) in Berkshire pigs.

\section{H-FABP (HaeIII)}

Genotype structure of pig H-FABP (HaeIII) gene was: genotype DD (0.194), Dd (0.494) and dd (0.312). The allele frequency was $\mathrm{D}(0.441)$ and $\mathrm{d}(0.559)$. The similar results were reported by Gerbens et. al. (1997) in the Dutch Landrace and Duroc breeds (0.32 and 0.40). Lee et al. (2010) confirmed a slightly higher occurrence of allele D (0.56).

LEPR (HpaII) 
All three genotypes were identified for LEPR in the group of pigs (AA - 0.137, AB - 0.314, BB - 0.549). Higher frequency of $L E P R$ gene was confirmed for allele B (0.706) against allele A (0.294). Stratil et al. (1998) reported similar results, where the B allele was the predominant in the Landrace, Meishan, Large White and Czech meat pig. Amills et al. (2008) confirmed a high occurrence of pigs with genotype BB (0.659) in the breed Landrace.

\section{MC5R (BsaHI)}

We identified two genotypes in the group of pigs (AA - 0.348 and AG - 0.652); genotype GG was not found. In conformity with genotype structure, we recognize a higher frequency of allele $\mathrm{A}(0.674)$ compared with allele $\mathrm{G}(0.326)$. The highest occurrence individuals in the set have genotype AG $(0,652)$ while Kim et al. (2000) and Emnett et al. (2001) present abundance of homozygotes AA (Table 3-4.).

Genetic structure - genotypes and alleles frequencies of pigs $(\mathrm{N}=105)$

\begin{tabular}{|c|c|c|c|c|c|}
\hline Gene & \multicolumn{3}{|c|}{ Genotype } & \multicolumn{2}{c|}{ Allele } \\
\hline \multirow{2}{*}{ LEPR(HpaII) } & $\mathrm{AA}$ & $\mathrm{AB}$ & $\mathrm{BB}$ & $\mathrm{A}$ & $\mathrm{B}$ \\
\cline { 2 - 7 } & 0.137 & 0.314 & 0.549 & 0.294 & 0.706 \\
\hline \multirow{2}{*}{$\boldsymbol{M C 5 R}$ (BsaHI) } & $\mathrm{AA}$ & $\mathrm{AG}$ & $\mathrm{GG}$ & $\mathrm{A}$ & $\mathrm{B}$ \\
\cline { 2 - 6 } & 0.348 & 0.652 & - & 0.674 & 0.326 \\
\hline \multirow{2}{*}{$\boldsymbol{H F A B P}$ (Hinfl $)$} & $\mathrm{HH}$ & $\mathrm{Hh}$ & $\mathrm{hh}$ & $\mathrm{H}$ & $\mathrm{h}$ \\
\cline { 2 - 6 } & 0.504 & 0.412 & 0.084 & 0.710 & 0.290 \\
\hline \multirow{2}{*}{$\boldsymbol{H F A B P}$ (HaeIII) } & $\mathrm{DD}$ & $\mathrm{Dd}$ & $\mathrm{dd}$ & $\mathrm{D}$ & $\mathrm{d}$ \\
\cline { 2 - 6 } & 0.194 & 0.494 & 0.312 & 0.441 & 0.559 \\
\hline
\end{tabular}

Effectiveness of alleles genes function in pigs $(\mathrm{N}=105)$

\begin{tabular}{|l|c|c|c|c|}
\hline \multirow{2}{*}{ Gene } & \multicolumn{2}{|c|}{ Heterozygosity } & \multirow{2}{*}{ PIC } & \multirow{2}{*}{ EA } \\
\cline { 2 - 3 } & $\mathbf{H}_{\text {obs }}$ & $\mathbf{H}_{\text {exp }}$ & & \\
\hline LEPR $($ HpaII & 0.314 & 0.415 & 0.325 & 1.709 \\
\hline MC5R $($ BsaHI) & 0.652 & 0.450 & 0.326 & 1.799 \\
\hline HFABP Hinfl $)$ & 0.412 & 0.420 & 0.326 & 1.700 \\
\hline $\boldsymbol{H F A B P}$ (HaeIII) & 0.493 & 0.451 & 0.372 & 1.980 \\
\hline
\end{tabular}

\section{CONCLUSIONS}

The genotypes of the leptin receptor (LEPR - HpaII), MC5R (BsahI) and cardio-fatty acid binding protein (H-FABP - Hinfl, HaeIII) genes were determined for the hybrid pigs. The PCR- RFLP methods were used for genotyping. These genes were suggested as candidate genes for fat content in pig meat.

\section{ACKNOWLEDGEMENT}

This article was part of the project VEGA 1/0061/10

\section{REFERENCES}

Amills, M.-Villalba, D.- Tor, M.- Mercadé, A.- Gallardo, D.-Cabrera, B.- Jiménez, N.- Noguera, J. L.- Sànchez, A.- Estany, J. (2008): Plasma leptin levels in pigs with different leptin and leptin receptor genotypes. Journal of Animal Breeding and Genetics. Volume 125, 2008, Issue 4, p 228-233

Campfield, L. A.- Smith, F. J.- Guisez, Y.- Devos, R.- Burn, P. (1995): Recombination mouse OB protein: evidence for a peripheral signal linking adiposity and central neural networks. Science. vol. 269, 1995, p. 546-549.

Emnett, R.- Moeller, S. et al. (2001): Association Studies with Leptin Receptor, Melanocortin-4 Receptor, Melanocortin-5 Receptor, and Peroxisome Proliferator Activated Receptor- $\gamma$. In: Eastridge, M. L., Bacon, W. L., Knipe, C. L., Meeker, D. L., Turner, T. B., and Zartman, D. L. Research and Reviews: Swine 2001. (OARDC Special Circular; 185), 57-63.

Gerbens F.- Rettenberger G.- Lenstraj A.- Veerkamp J. H.- Tepas M. F. W. (1997): Characterization, chromosomal localization, and genetic variatio of the porcine heart fatty aci-binding protein gene. Mammalian genome 8, 328-332.

Keen-Rhinehart, E.-Kalra S. P. (2004): Leptin-receptor gene transfer into the arcuate nucleus of female fatty zucker rats using recombinant adeno-associated viral vectors stimulates the hypothalamo-pituitary-gonadal axis. Biol. Reprod. vol. 71, 2004, p. 266-272.

Kim, K. S.-Markund, S.-Rothschild, M. F. (2000): The porcine melanocortin 5-receptor (MC5R) gene: polymorphisms, linkage, and physical mapping. In: Animal Genetics, 31, 2000c, p. 230-231.

Kováčik, A.- Trakovická, A.- Bulla, J.- Rafayová, A.- Lieskovská, Z. (2010): The effect of LEPR, MC5R and H-FABP gene polymorphism on pig production traits, Potravinárstvo, 2010, Special No., 460-465

Lee, S.H.-Choi, Y.M.-Choe, J.H.-Kim, J.M.-Hong, K.C.-Park, H.C.-Kim, B.C, (2010): Association between polymorphisms of the heart fatty acid binding protein gene and intramuscular fat content, fatty acid composition, and meat quality in Berkshire breed, Meat Science, 2010, 86, 794-800 
Mindeková, S.- Trakovická, A.-Strapáková, E. (2006): Effects of genotypes LEPR and H-FABP on pigs production, Acta fytotechnica et zootechnica, 2006, Special No., 32-33

Nechtelberger, D.- Pires, V.-Söflkner, J.- Stur, I.-Brem, G.-Mueller, M.-Mueller, S. (2001): Intramuscular fat content and genetic variants at fatty acid-binding protein loci in Austrian pigs, J. Anim. Sci., 2001, 79, 2798-2804

Stratil, A.-Kopečný, M.-Moser, G. (1998): HpaII and RsaI PCR-RFLPs within an intron of the porcine leptin receptor gene (LEPR) and its linkage mapping. Anim. Genetics. vol. 29, 1998, p. 398-413.

Remesar, X.-Rafecas, I.-Fernandez-Lopez, J. A. - Alemany, M. (1997): Leptin. Medicinal Research Reviews. vol. 17, 1997, p. 225-234.

Sambrook, J.-Fritz, E. F.-Maniatis, T. (1989): Molecular cloning: A laboratory manual. $2^{\text {nd }}$ ed., Cold Spring Harb. Lab. Press, USA, 1989.

Vincent, A. L.-Wang, L.-Rothschild, M. F. (1997): Rapid communication: a restriction fragment length polymorphism in the porcine leptin receptor (LEPR) gene. J. Animal Science. vol. 75, 1997, p. 2287. 